\title{
Sistem Pakar Bimbingan dan Konseling Terhadap Perilaku Siswa Menggunakan Metode Backward Chaining Berbasis Web
}

\author{
Elisya Permata Sari \\ Politeknik Pertanian Negeri \\ Samarinda \\ Teknologi Rekayasa Perangkat \\ Lunak \\ Manajemen Pertanian \\ Samarinda, Indonesia \\ epsari56@gmail.com
}

\author{
Eny Maria \\ Politeknik Pertanian Negeri \\ Samarinda \\ Teknologi Rekayasa Perangkat Lunak \\ Manajemen Pertanian \\ Samarinda, Indonesia \\ mariaeny.siringo2@gmail.com
}

\author{
Annafi' Franz \\ Politeknik Pertanian Negeri \\ Samarinda \\ Teknologi Rekayasa Perangkat Lunak \\ Manajemen Pertanian \\ Samarinda, Indonesia \\ annafifranz@gmail.com
}

\begin{abstract}
Abstrak-Bimbingan dan Konseling di sekolah merupakan metode yang diterapkan untuk mengontrol pribadi dan perilaku siswa-siswi yang memiliki masalah. Aplikasi ini menghasilkan keluaran berupa kemungkinan perilaku siswa berdasarkan gejala atau fakta yang dirasakan oleh siswa. Oleh karena itu tujuan dari penelitian ini adalah membangun aplikasi sistem yang dapat digunakan oleh guru BK (Bimbingan Konseling) untuk memberi bimbingan dan konseling terhadap siswa dengan cara melakukan konsultasi untuk siswa yang mengalami permasalahan terhadap perilakunya. Hasil dari penelitian ini diharapkan mempermudah guru BK dalam melakukan bimbingan dan konseling serta alat atau sarana pendekatan guru BK dengan siswa yang bermasalah dalam perilaku
\end{abstract}

Kata Kunci-Backward Chaining, Bimbingan Dan Konseling.

\section{PENDAHULUAN}

Pendidikan adalah usaha sadar dan terencana untuk mewujudkan suasana belajar serta aktif mengembangkan potensi dirinya untuk memiliki kekuatan spiritual keagamaan, pengendalian diri, kepribadian, kecerdasan, akhlak mulia, serta keterampilan yang diperlukan dirinya, masyarakat, bangsa dan negara. Pendidikan adalah proses pengubahan sikap dan tatalaku seseorang atau kelompok orang dalam usaha mendewasakan manusia melalui upaya pengajaran dan pelatihan, proses, cara, perbuatan mendidik (Pusat Bahasa Departemen Pendidikan Nasional, 2002:263)

Pendidikan merupakan hal yang amat sangat penting bagi anak-anak, karena merekalah generasi penerus bangsa yang diharapkan membawa perubahan bagi bangsa Indonesia. (Menurut Undang-Undang No 20 Tahun 2003).

Perkembangan dunia teknologi informasi sangat berkembang pesat, segala hal yang menggunakanan unsur teknologi selalu dapat diterima dengan baik dikalangan masyarakat. Di dunia kerja teknologi tentunya dapat mempermudah serta mengefisienkan waktu pekerjaan.Tidak ketinggalan dunia pendidikan pun sangat menikmati pesatnya perkembangan teknologi, bahkan dapat dikatakan dunia pendidikan sangat memerlukan teknologi demi keberlangsungan pendidikan.

Banyak dampak positif yang dibawa teknologi bagi dikehidupan sehari-hari, tetapi tak sedikit dampak negatif yang ditimbulkan dari teknologi itu sendiri, adanya penggunaan serta penyalahgunaan sarana informasi seperti "gadget", yang dimana hampir seluruh lapisan masyarakat memilikinya tak terkecuali remaja dan anakanak dibawah umur, dimana mereka seharusnya menghabiskan waktu luang bersama teman-teman seumurnya tetapi mereka lebih memilih menghabiskan waktu dengan bermain "gadget" atau "komputer" yang mereka miliki. Besarnya peran orang tua dalam mengawasi perilaku anak-anak sangat diharapkan. Remaja sekarang ini mudah terpengaruh oleh pergaulan bebas, adanya budaya ikut-mengikuti "tren-tren" terbaru atau budaya barat membuat mereka semakin lepas dari pantauan orang tua mereka sendiri, pergaulan bebas pun mengubah perilaku remaja sekarang ini lebih agresif dan mudah tersingung, sekolah yang merupakan sarana pendidikan yang diharapkan membentuk karakter mereka sepertinya hanya sedikit memberi harapan, guru yang merupakan orang tua kedua disekolah tidak lagi menjadi panutan mereka dalam berperilaku.

Kebiasaan maupun perilaku siswa khususnya disekolah dapat diminimalis dengan adanya guru yang bisa melakukan pendekatan psikologis hingga terciptanya komunikasi untuk memecahkan permasalah yang tengah dihadapi siswa. Guru tersebut harus mempunyai keahlian khusus dalam bidang psikologis yang mampu membimbing serta memberikan masukan kepada siswa

Guru bimbingan konseling adalah seorang guru yang bertugas memberikan bantuan psikologis dan kemanusiaan secara ilmiah dan profesional sehingga seorang konselor harus berusaha menciptakan komunikasi yang baik dengan murid dalam menghadapi masalah dan tantangan hidup (Sukardi, 2008).

Berdasarkan uraian permasalahan tersebut, maka penulis memutuskan untuk mengambil judul "Sistem Pakar Bimbingan dan Konseling Terhadap Perilaku Siswa Menggunakan Metode Backward Chaining Berbasis Web" dalam penulisan penelitian ini. 
Berdasarkan latar belakang yang telah diuraikan, Bagaimana membangun suatu Sistem Pakar berbasis web untuk mengetahui perilaku siswa sekolah menengah pertama (SMP) sesuai pengetahuan pakar bimbingan dan konseling?

1. Sistem Pakar ini dibangun berbasis web.

2. Metode yang digunakan dalam adalah metode backward chaining.

3. Pengetahuan tentang perilaku siswa dan gejala di dapatkan dari pakar yaitu guru BK SMP Negeri 3 Samarinda, SMP Negeri 36 Samarinda dan SMP Negeri 10 Samarinda.

Tujuan dalam penelitian ini adalah membangun aplikasi sistem yang dapat digunakan oleh guru BK (Bimbingan Konseling) untuk memberi bimbingan dan konseling terhadap siswa dengan cara melakukan konsultasi untuk siswa yang mengalami permasalahan terhadap perilakunya.

Dengan aplikasi ini diharapkan dapat membantu guru BK dalam melakukan pendekatan kepada siswa, memberikan bimbingan dan konseling kepada siswa, serta memberikan arahan dan motivasi untuk memperbaiki tingkah lakunya.

\section{TINJAUAN PUSTAKA}

A. Bimbingan Dan Konseling

1. Pengertian Bimbingan

Pada dasarnya bimbingan merupakan upaya pembimbing untuk membantu mengoptimalkan individu. Donald G.Mortensen dan Alan M.Schmuller (dalam buku Nurihsan, 2006) menyatakan, "Guidance may defined as that part of the total education program that helps provide the personal apportunities and specialized staff service by which each individual can develop to the fullest of his abilities and capacities in term of the democratic idea". Model bimbingan yang berkembang saat ini adalah bimbingan perkembangan bersifat edukatif, pengembangan dan outreach. Bersifat edukatif karena titik berat layanan bimbingan perkembangan ditekankan pada pencegahan dan pengembangan, bukan korektif atau terapeutik, walaupun layanan tersebut juga diabaikan. Bersifat pengembangan karena titik sentral sasaran bimbingan adalah perkembangan optimal seluruh aspek kepribadian individu strategi atau upaya pokoknya memberikan kemudahan perkembangan melalui rekayasa lingkingan perkembangan. Bersifat outreach karena target populasi layanan bimbingan perkembangan tidak terbatas pada individu yang bermasalah, tetapi semua individu berkenaan dengan semua aspek kepribadiannya dalam semua konteks kehidupan (masalah, target inteverensi, setting, metode, dan lama waktu layanan). Teknik bimbingan yang digunakan meliputi teknik-teknik pembelajaran, pertukaran informasi, bermain peran, tutorial dan konseling (Muro dan Kirrman dalam buku Nurihsan, 2006). Bimbingan perkembangan dilingkungan pendidikan merupakan pemberian bantuan kepada seluruh peserta didik yang dilakukan secara berkesinambungan agar mereka dapat memahami dirinya, lingkungan dan tugas-tugas sehungga mereka sanggup mengarahkan diri, menyesuaikan diri, serta bertindak wajar sesuai dengan keadaan dan tuntutan lembaga pendidikan, keadaan keluarga, masyarakat dan lingkungan kerja yang akan dimasukinya kelak. Dengan pemberian layanan bimbingan, mereka lebih produktif, dapat menikmati kesejahteraan hidupnya dan dapat memberi sumbangan yang berarti pada lembaga tempat mereka bekerja kelak, serta masyarakat pada umumnya. Pemberian bimbingan juga membantu mereka mencapai tugas-tugas perkembangan secara optimal.

1. Pengertian Konseling

Konseling adalah upaya membantu individu melalui proses interasik yang bersifat pribadi antara konselor dan konseli mampu memahami diri dan lingkungannya, mampu membuat keputusan dan menentukan tujuan berdasarkan nilai yang diyakininya sehingga konseli merasa bahagia dan efektif perilakunya.

Lebih jauh, Pietrofesa dan kawan-kawan menunjukkan sejumlah ciri-ciri konseling professional sebagai berikut:

a. Konseling merupakan suatu hubungan professional yang diadakan oleh seorang konselor yang sudah dilatih untuk pekerjaannya itu.

b. Dalam hubungan yang bersifat professional itu, klien mempelajari keterampilan pengambilan keputusan, penyelesaian masalah, serta tingkah laku atau sikap-sikap baru.

c. Hubungan professional itu dibentuk berdasarkan kesukarelaan antara klien dan konselor.

ASCA (American School Counselor Assosiation) mengemukakan, bahwa konseling adalah hubungan tatap muka yang bersifat rahasia, penuh dengan sikap penerimaan dan pemberian kesempatan dari konselor kepada klien. Konselor mempergunakan pengetahuan dan keterampilannya untuk membantu klien mengatasi masalahmasalahnya.

\section{Sistem Pakar}

Sistem Pakar (expert system) merupakan cabang dari Artificial Intelligenci (AI) yang cukup tua karena sistem ini mulai dikembangkan pada pertengahan 1960. Sistem Pakar yang muncul pertama kali adalah General-purpuse problem solver (GPS) yang dikembangkan oleh Newel dan Simon. Sampai saat ini sudah banyak Sistem Pakar yang dibuat, seperti MYCIN untuk diagnosa penyakit, DENDRAL untuk mengidentifikasi struktur molekul campuran yang tidak dikenal, XCON \& XSEL untuk membantu konfigurasi sistem komputer besar, SOPHIE untuk analisa sirkuit elektronik, Prespector digunakan dibidang geologi untuk membantu mencari dan menemukan 
deposit, FOLIO digunkan untuk membantu memberikan keputusan bagi seorang manager dalam stok dan investasi, DELTA dipakai untuk pemeliharaan lokomotif listrik diesel, dan sebagainya.

Istilah Sistem Pakar berasal dari istilah knowledge-based expert system. Istilah ini muncul karena untuk memecahkan masalah, Sistem Pakar menggunakan pengetahuan seorang pakar yang dimasukkan ke dalam komputer. Seseorang yang bukan pakar menggunkan Sistem Pakar untuk knowledge assistant. Sistem Pakar adalah sebuah sistem yang menggunakan pengetahuan manusia dimana pengetahuan tersebut dimasukkan kedalam sebuah komputer dan kemudian digunakan untuk menyelesaikan masalah-masalah yang biasanya membutuhkan kepakaran atau keahlian manusia (Turban dalam Sutojo dkk, 2010).

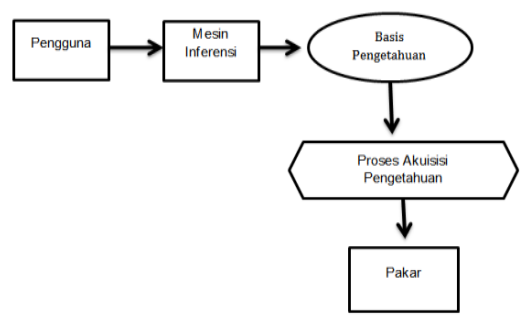

Gambar 1. Diagram Struktur Sistem Pakar

\section{Metode Backward Chaining}

Salah satu metode inferensi yang digunakanan dalam Sistem Pakar, yaitu Backward Chaining yang merupakan metode inferensi yang bekerja mundur kearah kondisi awal. Proses diawali dari Goal (yang berada dibagian THEN dari rule IF-THEN), kemudian pencarian mulai dijalankan untuk mencocokkan apalah fakta-fakta yang ada cocok dengan premis-premis dibagian IF. Jika cocok, rule dieksekusi, kemudian hipotesis dibagian THEN ditempatkan dibasis data sebagai fakta baru. Jika tidak cocok, simpan premis dibagian IF ke dalam stack sebagai subGoal. Proses berakhir jika Goal ditemukan atau tidak ada rule yang bisa membuktiksn kebenaran dari subGoal atau Goal.

\section{METODE PENELITIAN}

A. Alat dan Bahan

Alat dan bahan yang akan digunakan dalam penelitian Sistem Pakar Bimbingan dan Konseling Pada Perilaku Siswa sebagai berikut:

1. Alat

a. Perangkat keras

1) Laptop (RAM 4GB DDR3 Memory, AMD E1-2500, 14.0" HD LED LCD, 500 GB HDD).

2) Akses Internet

b. Perangkat lunak

1) Xampp Versi 3.2.2

2) Sublime Text

3) Browser Google Chrome/Mozila Fire Fox

4) Bootsrap/CSS
2. Bahan

\section{5) PhpMyAdmin}

a. Data perilaku siswa dan gejala.

b. Berdasarkan hasil penelitian yang dilakukan di 3 sekolah yaitu SMP Negeri 3 Samarinda, SMP Negeri 36 Samarinda dan SMP Negeri 10 Samarinda didapatkan data-data perilaku dan gejala dari guru bimbingan dan konseling.

Tabel 1. Data Perilaku

\begin{tabular}{|c|c|c|c|}
\hline No & $\begin{array}{c}\text { Perilak } \\
\text { u }\end{array}$ & Penyebab & Solusi \\
\hline $\mathrm{P} 1$ & Bolos & $\begin{array}{l}\text { Penyebabny } \\
\text { a bisa dari } \\
\text { dalam diri } \\
\text { siswa, } \\
\text { contohnya } \\
\text { merasa } \\
\text { jenuh atau } \\
\text { memiliki } \\
\text { masalah }\end{array}$ & $\begin{array}{l}\text { 1. Pikirkan dan bayangkan } \\
\text { apa yang akan terjadi } \\
\text { dimasa depan apabila } \\
\text { anda melakukan } \\
\text { perilaku-perilaku yang } \\
\text { tidak baik. } \\
\text { 2. Belajar berkata TIDAK } \\
\text { atau menolak apabila } \\
\text { teman mengajak sesuatu }\end{array}$ \\
\hline
\end{tabular}

pribadi

Dari luar diri

siswa yang tidak baik.

contonhya,

ajakan dari

(LAKUKAN BIMBINGAN

DAN KONSELING

teman-teman

DENGAN GURU BK

atau sekedar

ikut-ikutan.

P2 Malas Beberapa

penyebab

rasa malas

diantaranya,

sedang sakit,

kelelahan,

beban tugas

yang

diberikan,

cara

mengajar

dari

bapak/ibu

guru, kurang

tertarik

dengan mata

pelajaran

atau siswa

sedang

memiliki

masalah

pribadi .

P3 Kesulit Kurangnya

an motivasi

belajar belajar pada

dalam siswa, tidak

bidang berkonsentra

tertentu si atau

kondisi

ANDA)

belajar yang

tidak

kondusif
1. Pikirkan dan bayangkan apa yang akan terjadi dimasa depan apabila anda melakukan tindakan-tindakan yang tidak baik.

2. Cobalah kegiatan yang dapat membuat bahagia, lakukan bersama dengan teman bukan dengan gadget.

3. Apabila mengalam kesulitan memahami mata pelajaran coba tanyakan kepada guru yang bersangkutan dan memintanya untuk menjelaskan ulang.

(LAKUKAN BIMBINGAN DAN KONSELING DENGAN GURU BK ANDA)

1. Apabila mengalami kesulitan memahami mata pelajaran coba tanyakan kepada guru yang bersangkutan dan memintanya untuk menjelaskan ulang.

2. Sampaikan kepada guru wali kelas atau guru BK bagaimana gaya belajar yang diinginkan.

3. Belajar bersama teman saat waktu luang dan perbanyak membaca buku pelajaran. 


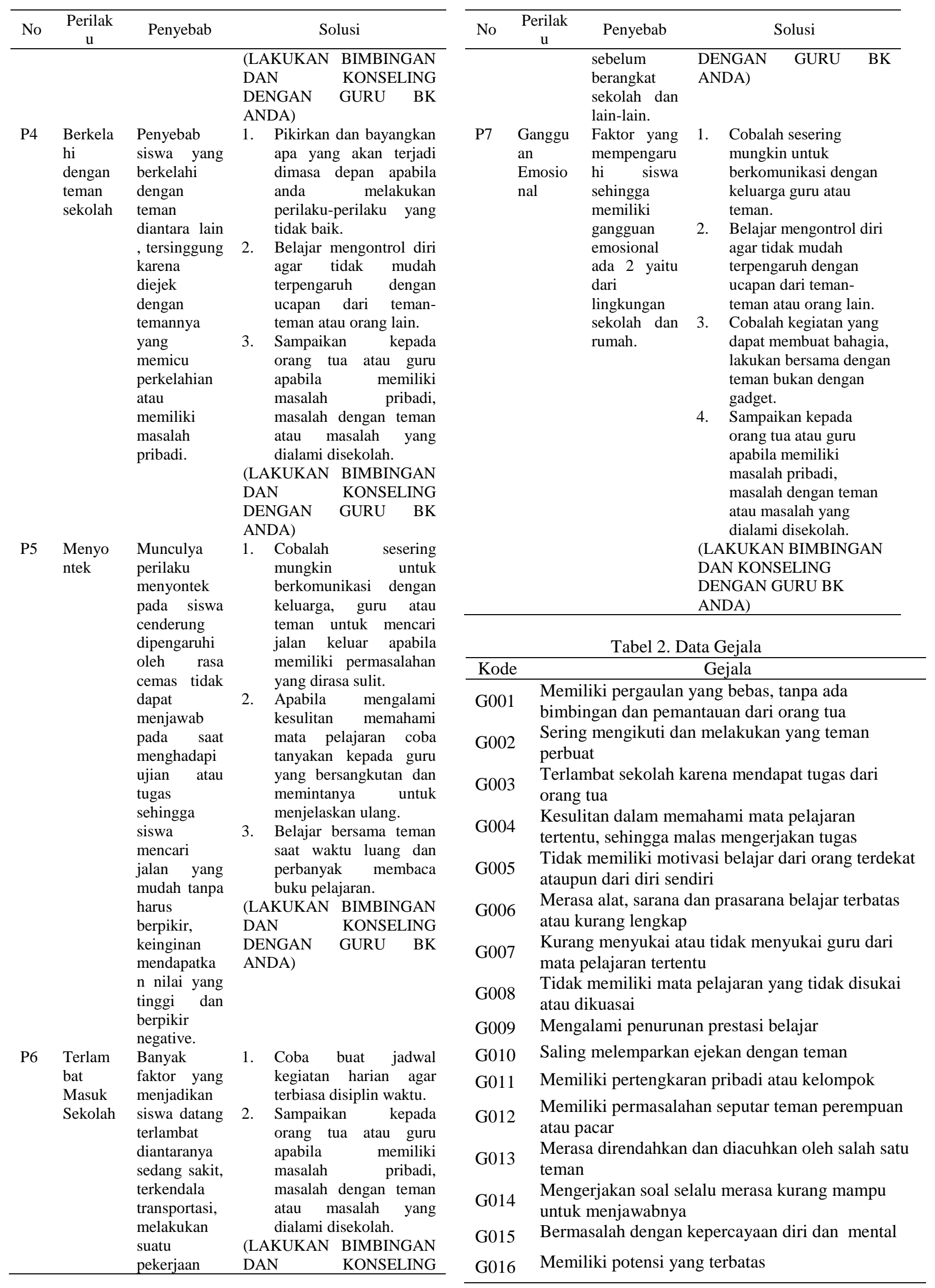




\begin{tabular}{|c|c|}
\hline Kode & Gejala \\
\hline G017 & $\begin{array}{l}\text { Mengalami kesulitan mendapatkan angkutan } \\
\text { umum atau transportasi ke sekolah }\end{array}$ \\
\hline G018 & Sering bangun kesiangan \\
\hline G019 & $\begin{array}{l}\text { Bermasalah dengan tanggung jawab yang harus } \\
\text { diterima }\end{array}$ \\
\hline G020 & $\begin{array}{l}\text { Merasa tidak nyaman dalam kondisi apapun, } \\
\text { dikarenakan terpengaruh dengan permasalahn yang } \\
\text { sedang dihadapi keluarga }\end{array}$ \\
\hline G021 & Memiliki masalah dengan diri, teman dan keluarga \\
\hline G022 & $\begin{array}{l}\text { Orang yang tidak sabaran, mudah marah dan sering } \\
\text { terpengaruhi }\end{array}$ \\
\hline G023 & Memiliki sifat iri terhadap teman dan keluarga \\
\hline
\end{tabular}

Pembentukan rule yang dipakai dalam sistem. Contoh pada pembentukan rule pertama, apabila siswa bolos maka siswa tersebut memiliki pergaulan yang bebas tanpa ada bimbingan dan pemantauan dari orang tua DAN sering mengikuti dan melakukan yang teman perbuat AND terlambat sekolah karena mendapatkan tugas dari orang tua DAN sering bangun kesiangan.

Tabel 3. Tabel Pembentukan Rule

\begin{tabular}{lll} 
Rule & THEN & IF \\
\hline R1 & P1 & G001 \& G002 \& G003 \& G018 \\
R2 & P2 & G004 \& G005 \& G006 \& G007 \\
R3 & P3 & G007 \& G008 \& G009 \& G015 \\
R4 & P4 & G010 \& G011 \& G012 \& G013 \\
R5 & P5 & G008 \& G014 \& G015 \& G016 \\
R6 & P6 & G003 \& G017 \& G018 \& G019 \\
R7 & P7 & G020 \& G021 \& G022 \& G023 \\
\hline
\end{tabular}

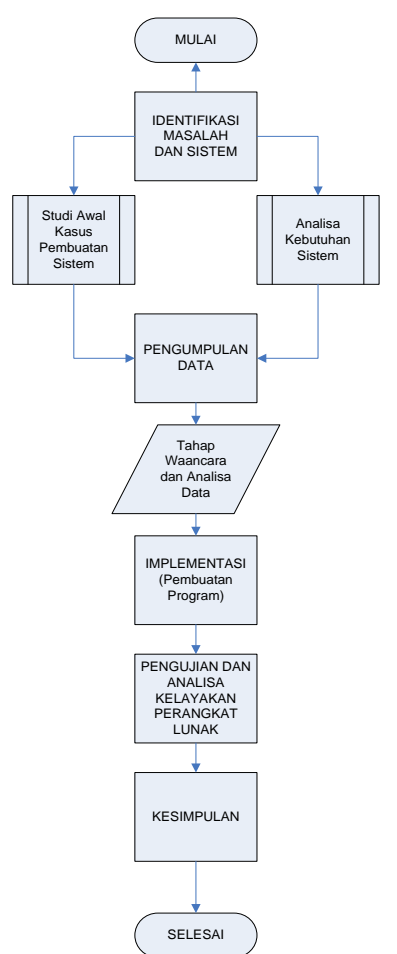

Gambar 2. Langkah-angkah Penelitian

1. Identifikasi Masalah dan Sistem

Melakukan identfikasi pada suatu masalah yang merupakan tahap awal pada proses penelitian. Tahap ini dilakukan agar penelitian benar-benar dapat menemukan masalah ilmiah. Tahap ini dibangun berdasarkan rumusan masalah yang didasari atas latar belakang masalah. Memahami teori-teori yang digunakan dan mencari faktor-faktor yang menjadi syarat Sistem Pakar Bimbingan dan Konseling Terhadap Perilaku Siswa dengan mengumpulkan studi literature seperti jurnal nasional atau internasional, buku bacaan dan browsing internet. Tahap identifikasi sistem dilakukan untuk memenuhi kebutuhan sistem baik data, perangkat keras maupun perangkat lunak.

2. Pengumpulan Data

Tahap ini merupakan cara mengumpulkan data yang dilakukan dengan wawancara kepada pihak guru BK sekolah SMP yang dituju.

3. Pembuatan ProgramTahap ini merupakan tahap membangun sistem sesuai dengan masalah yang didapatkan sebelumnya, merancang desain sistem atau model serta mengimplementasikan metode Backward Chaining kedalam program yang akan dibuat.

4. Pengujian Sistem

Merupakan tahapan pengujian sistem yang berhasil dibuat dan juga menganalisa kelayakan sistem.

5. Kesimpulan

Kesimpulan merupakan tahap akhir dari uraian proses penelitian dengan menyimpulkan permasalahan yang ada. 


\section{Model Anaisa}

Model representasi aliran proses perangkat lunak yang akan dirancang disajikan dalam Context Diagram dan Data Flow Diagram (DFD). DFD digunakan untuk menggambarkan aliran informasi dan proses data yang bergerak dari input data hingga output. CD dan DFD memudahkan pengguna yang kurang menguasai bidang komputer untuk mengerti sistem yang akan dikerjakan atau dikembangkan.

Context Diagram terdiri dari 2 (dua) entity yaitu pakar (Admin) dan pengguna (user). Admin memberikan input ke sistem berupa data nama perilaku, gejala serta informasi tentang perilaku. User dalam mendiagnosa perilaku memberikan gejala-gejala kepada sistem yang merupakan fakta dan selanjutnya sistem memberikan hasil konsultasi yang sesuai.

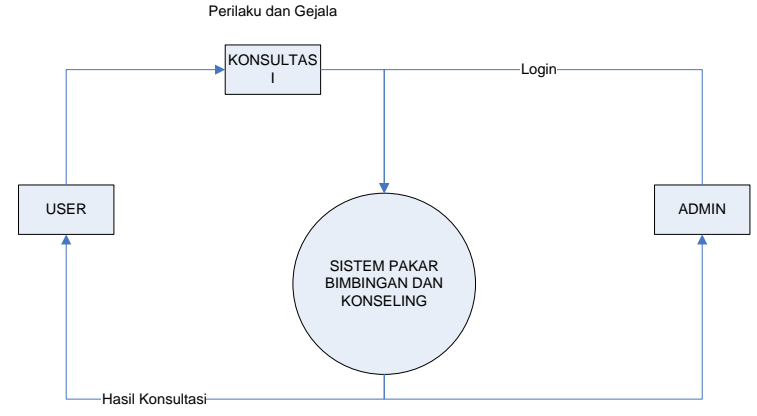

Gambar 2. Context Diagram

Data Flow Diagram (DFD) level 1 terdiri dari 5 yaitu konsultasi, proses konsultasi login admin, input data perilaku dan gejala, input basis pengetahuan. Proses yang pertama yaitu konsultasi, user diarahkan ke halaman konsultasi dengan memilh perilaku yang sesuai lalu diarahkan ke proses konsultasi dimana proses ini akan menampilkan gejala-gejala menyesuaikan perilaku yang telah dipilih oleh user. Kemudian proses konsultasi akan mengambil data dari proses basis pengetahuan untuk mendapatkan hasil konsultasi yang akan diberikan untuk user. Pada admin sebelum mengolah sistem pakar admin diarahkan ke proses login terlebih dahulu dengan memasukkan nama dan password setelah itu admin dapat menambah, mengubah, menghapus data-data perilaku dan gejala yang tersimpan di dalam database .

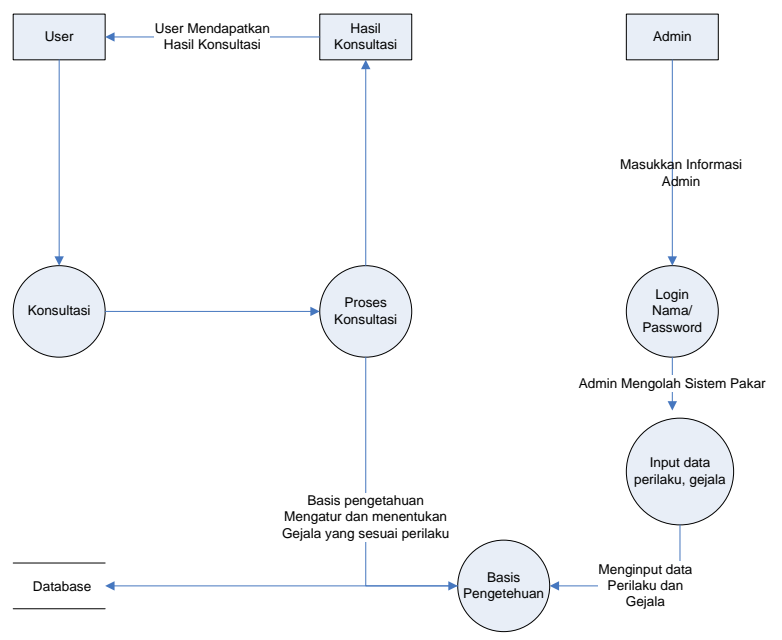

\section{Gambar 3. DFD Level 1}

ERD digunakan untuk menggambarkan mengenai berelasinya antar entitas. Pada gambar 6 berikut merupakan erd Sistem Pakar Bimbingan dan Konseling Menggunakan Metode Backward Chaining Berbasis Web ini. Dimana terdapat 6 entitas yang meliputi Admin, Masalah, Gejala, Basis Pengetahuan, Hasil dan Relasi.

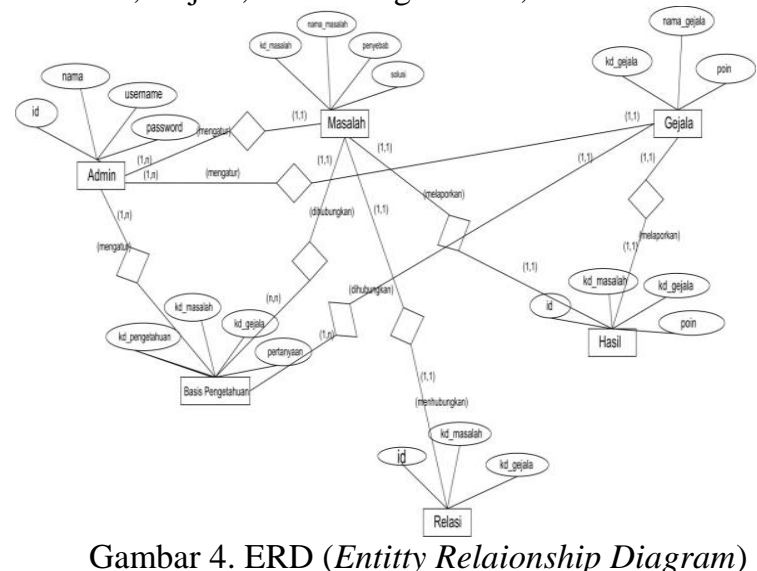

\section{HASIL DAN PEMBAHASAN}

A. Hasil

Berikut ini merupakan tampilan hasil dan pembahasan dari aplikasi Sistem Pakar Bimbingan dan Konseling Terhadap Perilaku Siswa Menggunakan Metode Backward Chaining Berbasis Web. Aplikasi ini dibangun sebagai sistem yang dapat membantu guru bimbingan dan konseling dalam melaksanakan bimbingan atau konseling terhadap siswa-siswanya.

1. Menu Beranda

Menu Beranda merupakan menu utama dari sistem pakar ini, pada menu ini terdapat menu bar yang berisikan menu cara penggunaan konsultasi, menu tentang dan menu admin untuk log in, user dapat langsung melakukan konsultasi dengan cara memilih menu konsultasi yang terdapat pada bagian menu bar.

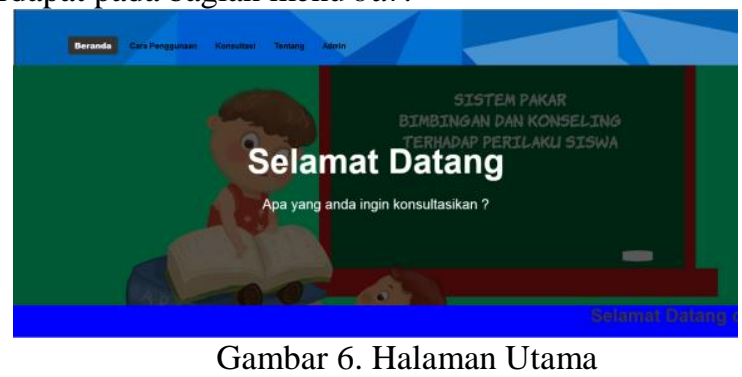

2. Pada menu ini user diarahkan untuk melakukan konsultasi dengan cara memilih jenis perilaku lalu diilanjutkan menjawab pertanyaan-pertanyaan yang sesuai dengan perilaku yang sudah dipilih sebelumnya setelah itu user akan mendapatkan hasil konsultasi. 


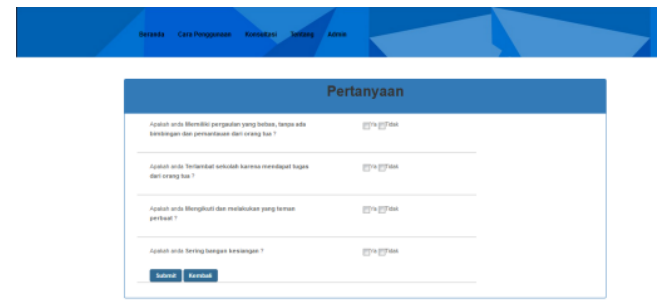

Gambar 7. Menu Konsultasi

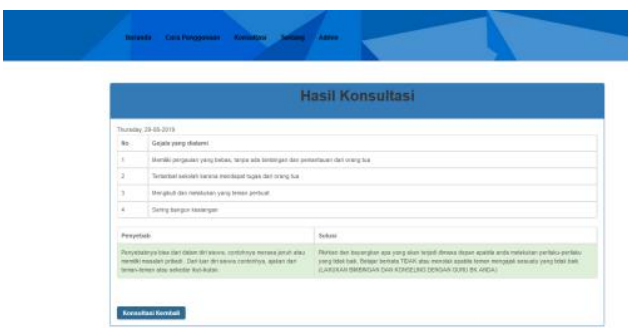

Gambar 5. Menu Hasil Konsultasi

3. Menu Tentang berisi informasi pengertian dari Sistem Pakar, Sistem Pakar Bimbingan dan Konseling.

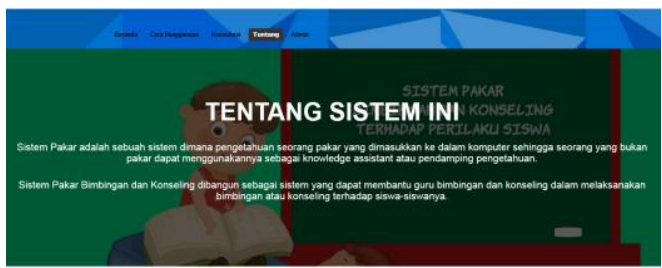

Gambar 9. Menu Tentang

4. Menu ini merupakan menu khusus yang hanya dapat diakses oleh admin atau pakar, admin/pakar terlebih dahulu melakukan log in dengan mengisi kolom username dan password, setelah itu admin akan diarahkan ke halaman admin/pakar yang berisikan beberapa menu yaitu, menu daftar perilaku, daftar gejala, daftar basis pengetahuan dan daftar admin.

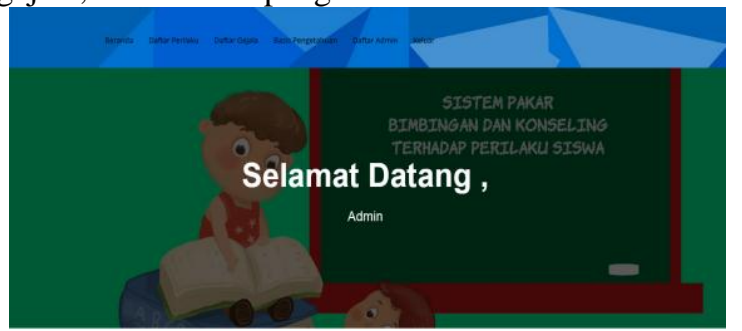

Gambar 10. Halaman Admin

5. Pada menu ini terdapat daftar-daftar perilaku yang berisi no, kode perilaku, nama perilaku, penyebab dan solusi. Admin dapat menambah, mengubah dan menghapus isi dari daftar perilaku.

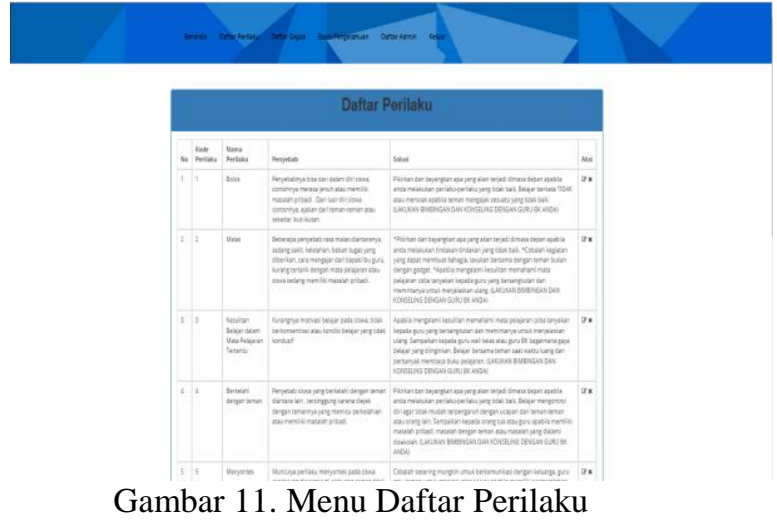

6. Pada menu ini terdapat daftar-daftar gejala yang berisi no, kode gejala, nama gejala dan poin. Admin dapat menambah, mengubah dan menghapus isi dari daftar gejala.

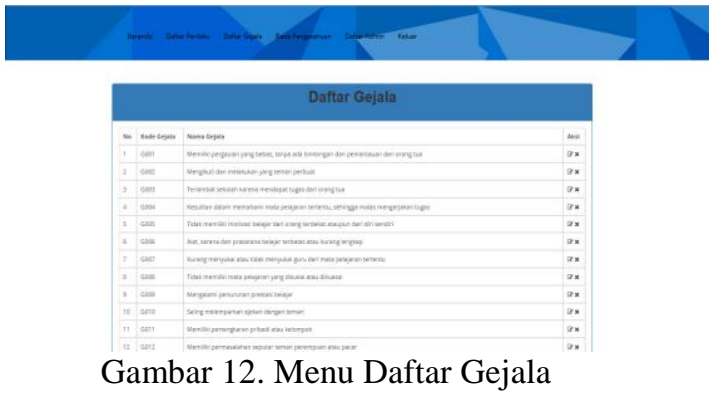

7. Pada menu ini terdapat daftar dari basis pengetahuan, admin dapat mengatur logika dasar, menambah, mengubah dan menghapus isi dari daftar basis pengetahuan.

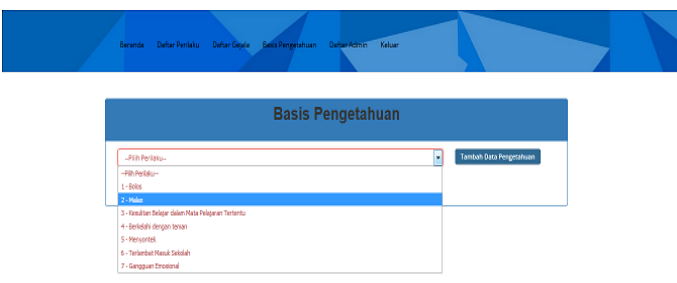

Gambar 13. Menu Basis Pengetahuan

8. Pada menu ini terdapat daftar admin yang berisi no, nama, username dan password, admin dapat menambah, mengubah dan menghapus isi dari daftar admin.

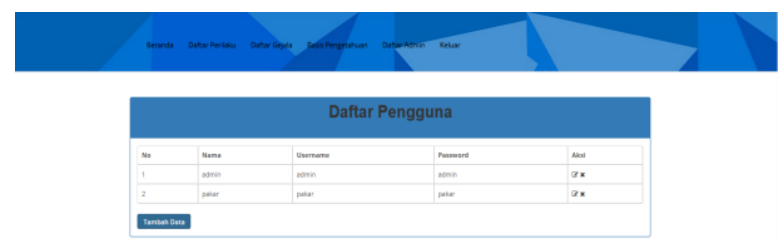

Gambar 14. Menu Daftar Pengguna 
B. Pembahasan

1. Pengujian Sistem

Untuk mencari kesalahan-kesalahan dalam sistem, digunakan metode pengujian black box.

Tabel 4. Pengujian Sistem

\begin{tabular}{|c|c|c|}
\hline Input & Output & Hasil Uj \\
\hline $\begin{array}{l}\text { Klik menu } \\
\text { Beranda }\end{array}$ & $\begin{array}{l}\text { Menampilkan } \\
\text { halaman utama }\end{array}$ & Berhasil \\
\hline $\begin{array}{l}\text { Klik menu } \\
\text { Konsultasi }\end{array}$ & $\begin{array}{l}\text { Menampilkan } \\
\text { halaman konsultasi } \\
\text { Menampilkan }\end{array}$ & Berhasil \\
\hline $\begin{array}{l}\text { Klik menu } \\
\text { Tentang }\end{array}$ & $\begin{array}{l}\text { halaman informasi } \\
\text { sistem pakar dan cara } \\
\text { penggunaannya }\end{array}$ & Berhasil \\
\hline $\begin{array}{l}\text { Klik Menu } \\
\text { Admin }\end{array}$ & $\begin{array}{l}\text { Menampilkan } \\
\text { halaman login admin }\end{array}$ & Berhasil \\
\hline $\begin{array}{l}\text { Klik tombol } \\
\text { Masuk }\end{array}$ & $\begin{array}{l}\text { Menampilkan menu } \\
\text { admin }\end{array}$ & Berhasil \\
\hline $\begin{array}{l}\text { Klik menu } \\
\text { Daftar } \\
\text { Perilaku }\end{array}$ & $\begin{array}{l}\text { Menampilkan } \\
\text { halaman daftar } \\
\text { perilaku }\end{array}$ & Berhasil \\
\hline $\begin{array}{l}\text { Klik menu } \\
\text { Daftar } \\
\text { Gejala }\end{array}$ & $\begin{array}{l}\text { Menampilkan } \\
\text { halaman daftar gejala }\end{array}$ & Berhasil \\
\hline $\begin{array}{l}\text { Klik Basis } \\
\text { Pengetahuan }\end{array}$ & $\begin{array}{l}\text { Menampilkan } \\
\text { halaman basis } \\
\text { pengetahuan }\end{array}$ & Berhasil \\
\hline $\begin{array}{l}\text { Klik menu } \\
\text { Daftar } \\
\text { Admin }\end{array}$ & $\begin{array}{l}\text { Menampilkan } \\
\text { halaman daftar admin }\end{array}$ & Berhasil \\
\hline $\begin{array}{l}\text { Klik menu } \\
\text { Keluar }\end{array}$ & $\begin{array}{l}\text { Keluar dari halaman } \\
\text { menu admin dan } \\
\text { kembali ke halaman } \\
\text { menu utama }\end{array}$ & Berhasil \\
\hline $\begin{array}{l}\text { Klik tombol } \\
\text { Tambah }\end{array}$ & $\begin{array}{l}\text { Menampilkan } \\
\text { halaman tambah data }\end{array}$ & Berhasil \\
\hline $\begin{array}{l}\text { Klik tombol } \\
\text { Edit }\end{array}$ & $\begin{array}{l}\text { Menampilkan } \\
\text { halaman edit data }\end{array}$ & Berhasil \\
\hline $\begin{array}{l}\text { Klik tombol } \\
\text { Hapus }\end{array}$ & $\begin{array}{l}\text { Dapat menghapus } \\
\text { data }\end{array}$ & Berhasil \\
\hline $\begin{array}{l}\text { Klik tombol } \\
\text { Simpan }\end{array}$ & $\begin{array}{l}\text { Dapat menyimpan } \\
\text { data }\end{array}$ & Berhasil \\
\hline
\end{tabular}

\section{Pengujian Validasi}

Pengujian validasi dilakukan untuk melihat sejauh mana sistem dapat bekerja seperti seorang pakar. Berdasarkan perhitungan validasi diperoleh nilai persentase dari 3 pakar yaitu pakar 1 nilai persentase sebesar 51,14\%, pakar 2 nilai persentase sebesar 42,85 $\%$ dan pakar 3 nilai persentase sebesar $100 \%$. Perbedaan hasil persentase ini terjadi karena terdapat gejala yang tidak ditemukan pada salah satu sekolah. Untuk memperoleh rata-rata nilai akurasi sistem berdasarkan nilai persentase dari 3 pakar dapat menggunakan perhitungan sebagai berikut (1) $\sum \frac{\text { Numiah nilai persentase }}{\text { jumlah keseluruhan persentase }} * 100 \%$

$$
\begin{aligned}
& =\frac{51,14+42,85+100}{100+100+100} * 100 \% \\
& =\frac{19 a_{2}, 99}{300} * 100 \%=64,66 \%
\end{aligned}
$$

Hasil dari perhitungan nilai akurasi tersebut adalah $64,66 \%$ menunjukkan bahwa sistem pakar ini berfungsi dengan baik sesuai dengan diagnosis pakar.

\section{KESIMPULAN}

Sistem Pakar Bimbingan dan Konseling dibangun untuk membantu guru BK mengetahui perilaku siswa dan melakukan pendekatan kepada siswa yang memiliki masalah dalam berperilaku. Sistem ini dapat memberikan konsultasi kepada siswa serta keluaran (output) berupa solusi dan arahan untuk siswa agar melakukan bimbingan dan konseling. Berdasarkan perhitungan validasi dari 3 pakar dengan 7 data perilaku serta 23 data gejala yang terhubung ke masing-masing perilaku dapat disimpulkan bahwa Sistem Pakar yang dibuat adalah 64,66\% berfungsi sesuai dengan diagnosis pakar.

Aplikasi ini masih banyak memilki kekurangan, untuk itu penulis berharap dalam pengembangan sistem dan aplikasi kedepannya dapat ditambahkan data pengetahuan, perilaku, gejala dan cara penanganan perilaku siswa oleh pakar sehingga cakupan data dan solusi yang disajikan lebih detail. Dalam sistem perlu ditambahkan data siswa yang telah melakukan konsultasi sebelumnya sehingga data tersebut dapat tersimpan sebagai arsip dan juga laporan untuk guru BK. Dapat dikembangankan lagi dengan melengkapi cetak form laporan konseling yang dapat dikirim kepada orang tua siswa yang telah melakukan perilaku-perilaku melampui batas berbentuk surat teguran atau melalui email dari orang tua siswa yang bersangkutan.

\section{DAFTAR PUSTAKA}

Arief, M.R. 2011. Pemrogaman web dinamis menggunakan PHP dan MySQL. Yogyakarta: Andi Offset.

Buana dan Astuti. 2017. "Sistem Pakar Bimbingan dan Konseling Siswa Bermasalah Dengan Menggunakan Metode Forward Chaining Pada Madrasah Aliyah Negeri 1 Brebes". Jurusan Teknik Informatika Fakultas Ilmu Komputer Universitas Dian Nuswanto Semarang, Semarang. (Hlm:1-4).

Departemen Pendidikan Nasional. 2002. Kamus Besar Bahasa Indonesia, Jakarta: Balai Pustaka.

Doro, E. dan Stevalin B. 2009. Analisis Data dengan Menggunakan

ERD dan Model Konseptual Data Warehouse. Bandung.

Fahli, M., Zatra, H.A., Muri, Y., Syahniar. (2013). "Perancangan Sistem Pakar Untuk Mengetahui Infertilitas Pada Perempuan Menggunakan Metode 
Certainty Factor Pemahaman Konselor Sekolah Tentang Tugas Perkembangan Siswa Dan Layanan Yang Diberikan". Padang: Fakultas Ilmu Pendidikan Universitas Negeri, Volume 2 Nomor 1.

Fatimah dan Maulana 2017. "Perancangan Sistem Pakar Permasalahan Siswa Di Sekolah". Sekolah Tinggi Teknologi Garut. Jurnal Algoritma Vol. 14, No. 2: 311-318.

Firman, Wowor dkk. 2016. " Sistem Informasi Perpustakaan Online Berbasis Web". Jurusan Teknik Elektro Fakultas Teknik UNSRAT. Jurnal Teknik Elektro dan Komputer. Vol. 5, No.2: 29-36.

Josi, A. (2017). Penerapan Metode Prototiping Dalam Pembangunan Website Desa, 50-57.

Nasir dan Jahro 2018. "Sistem Pakar Konseling dan Psikoterapi Masalah Kepribadian Dramatik Menggunakan Metode Forward Chaining Berbasis Web". Program Studi Teknik Informatika, Fakultas Teknik, Universitas Putera Batam, Batam. Jurnal Teknologi dan Sistem Informasi Univarb. Vol. 3, No. 1: 37-48.

Nurihsan 2006. Bimbingan dan Konseling Dalam Berbagai Latar Kehidupan, Bandung: PT Refika Aditama:7-17.

Putri 2018. "Sistem Pakar Untuk Mengidentifikasi Kepribadian Siswa Menggunakan Metode Certainty Factor Dalam Mendukung Pendekatan Guru”. Program Studi Sistem Komputer, Fakultas Sains dan Teknologi, Universitas Pembangunan Panca Budi, Medan. Jurnal of Information Technologi and Computer Science, Vol. 1, No. 1:78-90.

Saputra, A. (2012). Php, Html5 dan CSS3. Jakarta.

Sukardi, Dewa ketut. 2008. Proses Bimbingan dan Konseling Di Sekolah. Jakarta: Rineka Cipta.

Sutojo dkk 2010. Kecerdasan Buatan. Semarang: Andi Offset. Hlm:160-178.

Syah dan Gunawan. 2016. "Sistem Pakar Bimbingan dan Konseling Siswa Dengan Metode Certainty Factor Berbasis Web Pada SMAN 1 Cikembar. Seminar Nasional Ilmu Pengetahuan dan Teknologi Komputer Nusa Mandiri. ISBN:978-602-72850-33.(Hlm:85-94).

Undang-Undang Nomor 20 Tahun 2003 Tentang Sistem Pendidikan Nasional. 